\title{
Transition towards sustainable energy production: where does Bangladesh stand as the worst hit by climate change?
}

ABSTRACT: Bangladesh is the seventh climate risky country in the world located in South Asia. Progressive economic growth, rapid industrialization and other development efforts are transforming Bangladesh towards a middle-income country. To cope up with the rapid economic growth, the energy supply needs to match energy demand. On the other hand, energy is at the heart of the solution to climate challenge as two-thirds of global greenhouse gas emissions come from the energy sector. At present, around $62 \%$ of total electricity depends on gas-fired power generation but its stock is depleting fast due to the increased rate of extraction and use. Considering the shortage of natural resources and being a country worst hit by climate change, the existing state, future prospects, renewable energy policies in Bangladesh are needed to be evaluated to make the existing energy

$\triangle$ Corresponding Author: Md Moynul Ahsan; e-mail: moynulurp01@gmail.com

1 Department of Real Estate Development and Management, Ankara University, Turkey; ORCID iD: 0000-0003-0822-3850; e-mail: moynulurp01@gmail.com

2 Department of Electrical and Electronics Engineering, Gazi University, Turkey; ORCID iD: 0000-0003-1447-236X; e-mail: showrov1993@gmail.com

3 Department of Mechanical and Production Engineering, Islamic University of Technology (IUT), Bangladesh; ORCID iD: 0000-0002-5167-9135; e-mail: sakibhossain@iut-dhaka.edu

4 Department of Mechanical and Production Engineering, Islamic University of Technology (IUT), Bangladesh; ORCID iD: 0000-0001-5877-3784; e-mail: shajidsoad@gmail.com

2021. The Author(s). This is an open-access article distributed under the terms of the Creative Commons Attribution-ShareAlike International License (CC BY-SA 4.0, http://creativecommons.org/licenses/by-sa/4.0/), which permits use, distribution, and reproduction in any medium, provided that the Article is properly cited. 
sector more sustainable and modern. A thorough description from secondary sources of the energy sector in Bangladesh is provided in this paper with a special emphasis on the current scenario and future prospects of electricity generation, existing policy issues by using various renewable energy sources. Moreover, a comparison is made regarding the progress in renewable energy sector of Bangladesh with the countries most affected by global climate change. This comparison provides a perspective of how Bangladesh is progressing towards sustainable energy transition while facing problems due to climate change. Finally, recommendations are provided to advance the development of the existing energy sector of Bangladesh to turn it into a sustainable energy sector.

Keywords: energy sector, eenewable energy, climate change, energy policy, Bangladesh

\section{Introduction}

Bangladesh is one of the densely populated climate risky countries in the world with a population of around 166.5 million and in terms of population, Bangladesh ranks 8th globally (Worldometer 2021; Ahsan 2020). Therefore, the demand for energy is enormous and is increasing with the growth of its population over the past three decades. This trend is intensifying further due to its progressive economic growth, rapid urbanization, and industrialization. During the last decade, Bangladesh managed an economic growth rate of $6.2 \%$ which is higher than the global average (Baky et al. 2017). Bangladesh also aims to come out from being labelled as a lower-middle income country by the year 2021, and aims to be graduated into a higher middle income county by 2031 , and to become a developed nation by 2041 (General Economics Division 2020). To sustain the ongoing economic growth, the supply of energy should be increased to meet the growing demand. Moreover as the country is not rich in conventional fuels used in energy production such as coal, oil and gas, the smartest move for the country is to invest in Renewable Energy (RE) production.

Economic development is not the only driving force for increasing the RE production. Like many other countries, the risk of climate change and global warming has put Bangladesh in a vulnerable situation. According to the Global Climate Risk Index 2021, Bangladesh is one of the top 10 countries which are most affected in long term by climate change from 2000 to 2019 . To be specific, according to the indexing, Bangladesh ranked 7 among the countries worst hit by climate change (Eckstein at el. 2021). One of the main reasons behind worsening environmental condition worldwide is Global warming caused by excessive greenhouse gas (GHG) emission. The amount of GHG emission in Bangladesh is rapidly rising and it has increased by $91.9 \%$ from the energy sector starting from 1990 to 2018 (Climate Watch 2018). Hence, the government has coined several policies and adopted new strategies to incorporate sustainable energy resources to the energy sector in order to achieve environmental sustainability. The implementation of such policies and strategies is not taking place in a fast manner. A developing country like Bangladesh, with a vision to break in to the list of developed nations can benefit greatly from innovations to integrate renewable energy in the power sector. 
All these factors indicate that Bangladesh should place more emphasis on the transition towards a green and sustainable energy sector from a heavily dependent fossil-fuel based energy sector. However, the state-owned energy sector is suffering from large deficits, and failed to attract sufficient private investments in the past years. At present, the main source of energy generation in Bangladesh is natural gas, whose stock is depleting fast due to huge dependence on this source. Elevated cost of extraction due to thick seam on local coals, unfavorable location of the coal mines, environmental and health concerns are the major reasons for discouraging coal-fired energy production in Bangladesh. Therefore, the country has to depend on foreign countries to meet the demand of oil as there is no reserve. In spite of having many large water bodies, the height difference necessary to produce electricity during the high and low tide is not available.

To mitigate this serious problem, transition from conventional energy sources to sustainable energy production is a must. Moreover, there should be some degree of social responsibility among the government and policy makers all over the world on to ensure a sustainable future. Therefore, instead of blaming others (industrialized high carbon emission countries), it is necessary to take steps to make the transition towards making a sustainable energy system. Now, the main question is - being the countries which are facing the highest risk of climate change such as Puerto Rico, Myanmar, Haiti, Philippines, Pakistan, Vietnam and Bangladesh (Eckstein et al. 2021), how are these seven countries shaping their energy sectors to tackle the problem? How are they doing in terms of boosting the production capacity in their renewable resources effectively? Therefore firstly, this study provides a description of the renewable energy sectors, present scenarios and future prospects of renewable energy in Bangladesh. The significant energy policies taken to boost the renewable energy generation in Bangladesh is also included, and secondly, this study evaluates the progress of the renewable energy utilization in Bangladesh with countries which are worst hit by climate change. It can be stated here that all countries listed above have ratified the Paris Agreement except Puerto Rico but Puerto Rico joined the US Climate Alliance and is moving towards complete renewable energy based generation by 2050. As Bangladesh is facing alarming climate change risks due to global warming and other related impacts, this study will help to understand where Bangladesh is standing in transition towards sustainable energy generation from conventional energy usages being a serious victim of global warming.

\section{Methodology of the study}

A desk-based systematic survey on secondary literatures has been adopted in this study. The findings and reviews are drawn from the secondary information from peer-reviewed journal articles, national and international reports, scientific journals, conference papers, study reports, newspaper reports, etc., covering a description of energy sectors, present scenarios and future prospects of renewable energy in Bangladesh. A comparison of renewable energy sectors of countries facing the worst climate risks is provided by focusing on the standings and Bangladesh's 
position towards sustainable energy. Later on, general recommendations are provided based on the current state, future prospects and discussion. Though this study is limited to the secondary sources but this study provides a sustainable energy stance in greatly impacted countries with special focus on Bangladesh to be timely and of interest for the readership of multidisciplinary fields including policy, planning, engineering etc.

The followed methodological flow chart in this research is given below in Figure 1.

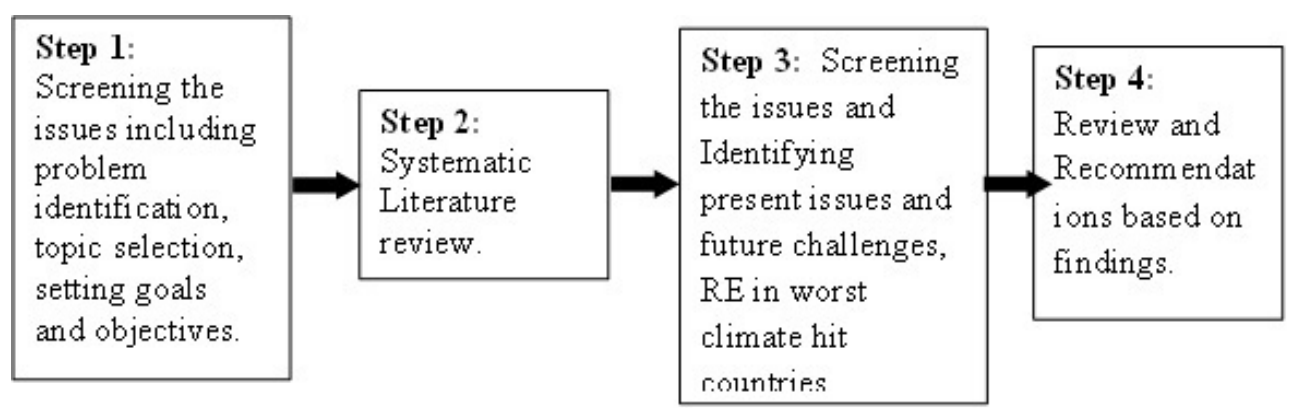

Fig. 1. Methodological flow chart in the research

Rys. 1. Metodologia prowadzonych badań - schemat

\section{Findings and analysis}

\subsection{Present energy sector of Bangladesh and future prospects}

The population and economy of Bangladesh are both rapidly growing and the trend is anticipated to be continued in the near future. In Bangladesh, around $65 \%$ people live in rural areas among whom only $78.3 \%$ people have access to electricity and approximately $35 \%$ people live in urban areas among whom $97.1 \%$ people have access to electricity (World Bank 2018). As mentioned earlier, rapid industrialization, economic growth and the surge of the population have driven the government of Bangladesh to boost the power generation capacity of the country exponentially over the years. Starting from 2007, the generation capacity of Bangladesh has increased thrice and the total capacity installed has become four times. A graphical representation of the peak electricity generation is shown in Figure 2 provided by the data published by Ministry of Power, Energy and Mineral Resources (MPEMR 2020).

As seen from Figure 2, the power generation in Bangladesh has rocketed since 2015 and at present the total generation capacity of Bangladesh exceeded 21000 MW (Imam 2021). However, still about 16 million people of the country do not have access to electricity in spite of such a mammoth development in the power sector (Bosu and Rafiq 2019). While the world is focusing towards renewable energy resources, Bangladesh still produces a major portion of its energy by 


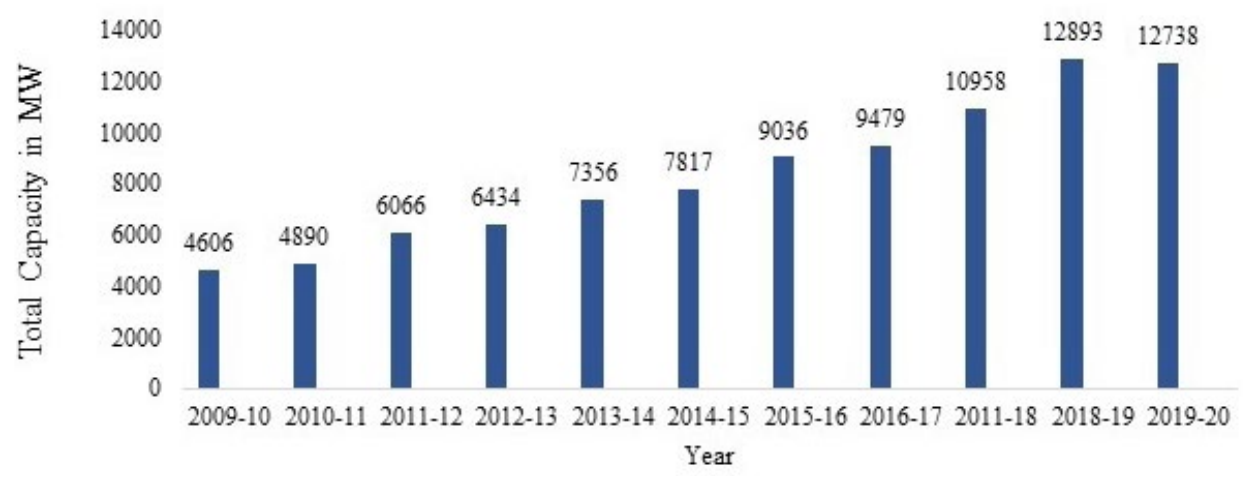

Fig. 2. Peak Electricity generation in Bangladesh from 2009-2010 fiscal year until 2019-2020

Rys. 2. Szczytowa produkcja energii elektrycznej w Bangladeszu w latach podatkowych 2009-2010 do 2019-2020

burning various fossil fuels like coal, natural gas, crude petroleum, diesel etc. Percentages of power generation utilizing different types of fuels are shown in Figure 3 (SREDA 2021).

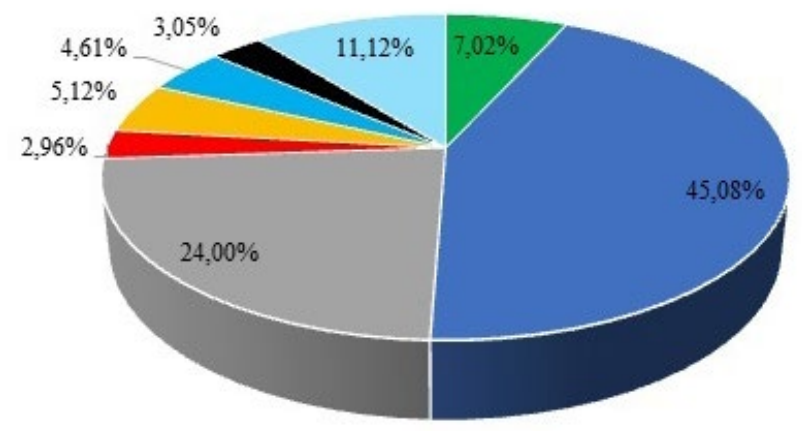

$$
\begin{aligned}
& \text { - Coal } \\
& \text { - Gas } \\
& \text { - Heavy fuel oil (HFO) } \\
& \text { - Coal } \\
& \text { - Diesel (HSD) } \\
& \text { - Imported } \\
& \text { - Renewable } \\
& \text { - Captive Energy }
\end{aligned}
$$

Fig. 3. Percentage of power generation from different sources

Rys. 3. Procentowe udziały produkcji energii elektrycznej z różnych źródeł

Bangladesh doesn't have much stock of fossil oil or coal and hence highly dependent on natural gas for energy production as about $45.08 \%$ power comes from this source alone (SREDA 2021). However, according to a survey conducted in 2015, the remaining gas stock of Bangladesh is 14.6 trillion cubic feet (TCF) and at the current rate of extraction the stock is expected to serve us for another decade or so (The Daily Star 2015). Although the discovery of 23 new gas fields of which two are in offshore areas are showing promises to be feasible energy sources in the near future (Masud et al. 2020). To conserve the natural gas resource, the Bangladesh government has taken necessary steps to limit the supply of new gas connections to industries and households. 
In Bangladesh, the proven reserve of coal is around 4,750 Metric tons (Sajjad and Rasul 2015). On the one side, coal is one of the cheapest fuels for electricity production. However, using coal for electricity production has a severe environmental impact. The government of Bangladesh has targeted to generate around 20,000 MW of electricity from coal-fired power projects by 2030 but on 27 June 2021 the government has cancelled 10 coal-based power plants out of 18 planned coal-based power plants considering their environmental impact (Roy 2021).

To utilize the available energy resources and to make a feasible plan, the government of Bangladesh undertook a plan called "Power System Master Plan (PSMP)" in 2010 (PSMP 2010). After that, a reviewed and updated version of the Master Plan was published with a five year plan from 2016 up to 2021 named the "Power System Master Plan (PSMP 2016)" (MPEMER 2016). In Figure 4, the projected electricity demand and the planned electricity production capacity is shown according to the data presented in PSMP 2016. It should be mentioned that the demand shown in Figure 3 is the peak demand with a high case without considering the Energy Efficiency \& Conservation measures. The demand data is collected from distribution utilities (132 kV level) (MW). Although this methodology disregards various factors, this provides a more simplified way to project the overall electricity demand in an easier way (MPEMER 2016).

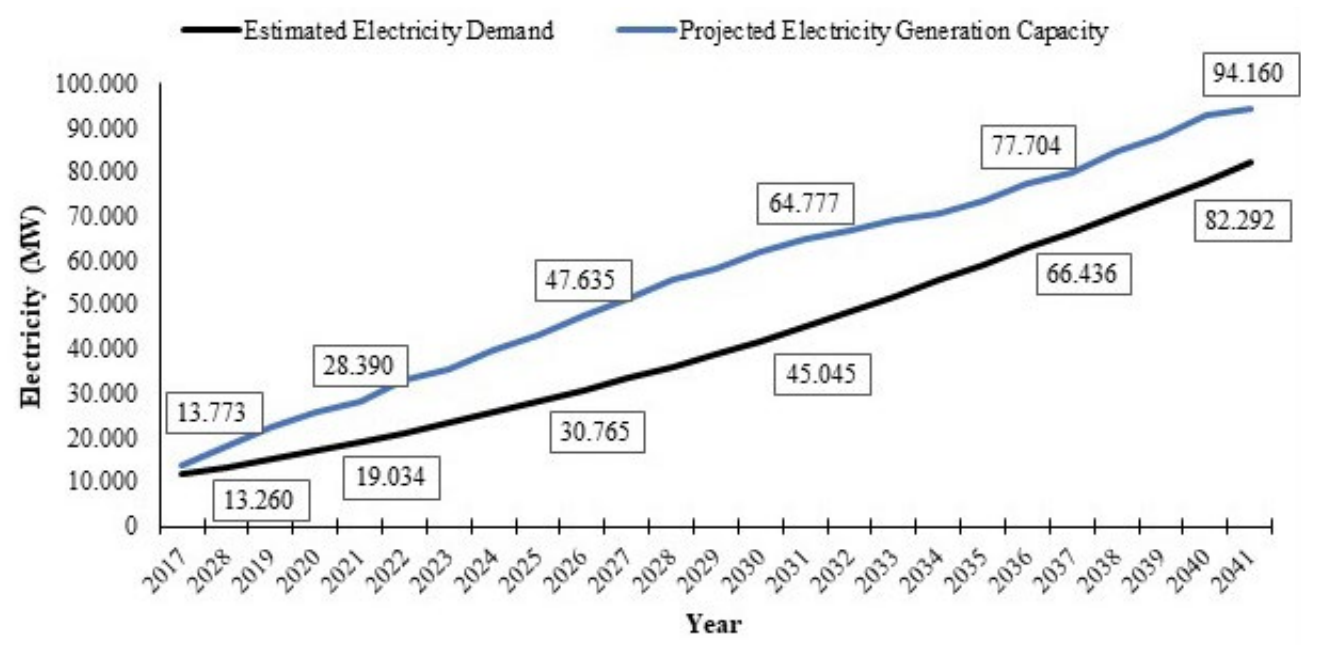

Fig. 4. Estimated electricity demand and projected electricity production capacity in Bangladesh (2017-2041) (PSMP 2016)

Rys. 4. Szacunkowe zapotrzebowanie na energię elektryczną i prognozowane moce produkcyjne w Bangladeszu $(2017-2041)$

As depicted in Figure 4, according to the PSMP 2016, the electricity production capacity of Bangladesh is projected to increase from 13,773 MW (in 2017) to 72,564 MW (in 2041) in 24 years' time period. As the production capacity increases, the production capacity from renewa- 
ble energy should also be increased. The current scenario and future prospects of utilization of renewable energy would be discussed in the following sections.

\subsection{Renewable energy usages in Bangladesh: current state, prospects and future plan}

The aim of the Bangladesh government is to break into the list of middle-income country from a developing country depends greatly on diversifying the power sector of the country and utilize sources like solar, wind, biogas, biomass etc. effectively (Masud et al. 2020). At present, renewable energy provides $16.7 \%$ of the total generated energy worldwide and owing to this there has been an increase of $17 \%$ of the total investment in this sector which should be an inspiring evidence for a developing nation like Bangladesh indicating that investment in this sector is rewarding (Erakhrumen 2014). In 2008, the Bangladesh government formulated a renewable energy stratagem where a target was set to produce $5 \%$ and $10 \%$ of the country's total energy from renewable sources by the year 2015 and 2020 respectively (MPEMER 2016). However, according to the energy mix data of the National Database of Renewable Energy in Sustainable and Renewable Energy Development Authority (SREDA), the renewable energy installed capacity in peak production capacity is 766.68 , and the share of RE in the energy mix is $3.05 \%$ only (SREDA 2021).

The current contribution of different renewable sources to the overall power generation from these sources is presented in Table 1 (SREDA 2021). The power generation capacity is given in Mega-Watt considering the peak generation capacity [MWp]. As seen from the table, mainly solar energy and hydro power drive the energy generation from renewable sources in Bangladesh. The contribution of wind, biogas and biomass are quite negligible.

TABLE 1. Power generation capacity of Bangladesh from different renewable energy sources

TABELA 1. Moce wytwórcze Bangladeszu z różnych źródeł energii odnawialnej

\begin{tabular}{|l|c|c|c|}
\hline \multicolumn{1}{|c|}{ Renewable Energy Sources } & Off-grid [MWp] & On-grid [MWp] & Total [MWp] \\
\hline Solar & 346.7 & 185.99 & 532.69 \\
\hline Wind & 2 & 0.9 & 2.9 \\
\hline Hydro & 0 & 230 & 230 \\
\hline Biogas to Electricity & 0.69 & 0 & 0.69 \\
\hline Biomass to Electricity & 0.4 & 0 & 0.4 \\
\hline Total & 349.79 & 416.89 & 766.68 \\
\hline
\end{tabular}

Source: SREDA 2021 


\subsubsection{Solar energy}

Solar energy provides an affordable and secure supply of renewable energy, and for Bangladesh it is the most prominent renewable energy resource for electricity production. Bangladesh being located $20^{\prime} 34 \mathrm{~N}$ to $26^{\prime} 38 \mathrm{~N}$ latitude and from $88^{\prime} 01 \mathrm{E}$ to $92^{\prime} 41 \mathrm{E}$ longitude and having a total area of 148,560 Sq Km (Bangladesh Bureau of Statistics 2019), is in a suitable position for utilizing solar energy. It has an average of $5 \mathrm{KWh} / \mathrm{m}^{2}$ per day of solar radiation over 300 days per year, and the maximum amount of radiation occurs in between March and April and the minimum on December to January period (Deb et al. 2013).

As a developing country, the most cost-effective and feasible utilization of solar energy in Bangladesh is the implementation of the Solar Home System (SHS). The SHS is a proven technology that is able to fulfill the basic electricity needs of people where grid expansion is challenging. It is also very effective when it comes to providing electricity to the people living in the rural area. Solar cells which are being currently used in Bangladesh are mostly the SHS and the SHS program in Bangladesh is now recognized as one of the fastest progressing dissemination programs in the world. SHS technology started its journey in Bangladesh in 2003 sponsored by the Infrastructure Development Company Limited (IDCOL) - a government owned specialized non-bank financial institution that finances various renewable infrastructure projects in Bangladesh. IDCOL has the target of installing 6 million SHS and generating $220 \mathrm{MW}$ of electricity by 2021 and solar pumps of $11 \mathrm{~kW}$ capacity numbering 50,000 throughout the country by 2025 (Hossain and Rahman 2021). It has installed more than 4.13 million systems across the country (Saim and Khan 2021). Moreover, IDCOL has established 11 solar-mini grids of capacity 2.19 MW have been established throughout the country. Apart from this, the Bangladesh Power Development Board (BPDB) in conjunction with the government of Bangladesh has completed multiple solar energy-based projects and plans to undertake several others with the assistance of the Climate Change Trust Fund (Bosu and Rafiq 2019).

The government is also promoting the installation of solar panels in public offices and places for lighting and heating purposes. According to SREDA, over 29 thousand solar lights have already been placed. In addition to these small size projects, multiple large-scale projects to harvest solar energy are going now including solar park, solar irrigation, solar battery charging system, solar drinking water system etc. Furthermore, the government has taken several initiatives to build solar grids in different scales. According to SREDA, a total of 27 solar micro-grids with $5.656 \mathrm{MW}$ capacity and 2 solar Nano-grids with $1 \mathrm{~kW}$ capacity have already been installed. However, Bangladesh needs extensive support from national and international donor agencies to implement the plan.

\subsubsection{Hydro energy}

Hydro energy in spite of not being a completely green source of energy has two key advantages over conventional sources like coal, natural gas, fossil fuel etc. which makes it an attractive 
source of power generation. First of all, once established, there is very little cost of power generation and secondly greenhouse gas emission is significantly lower.

Although Bangladesh is a riverine country but the prospect of hydro energy is quite limited due to the unavailability of required water head and water flow. Hence, there is only one large scale hydroelectric power plant in Bangladesh, located at Kaptai with a capacity of $230 \mathrm{MW}$ and the Bangladesh Power Development Board (BPDB) is now planning to increase its capacity further up to a $330 \mathrm{MW}$ level (Miskat et al. 2020). A small hydroelectric power plant was established in Rangamati in 2005 with a capacity of $50 \mathrm{~kW}$ (Miskat et al. 2020).

A survey is being jointly conducted by BPDB and the Bangladesh Water Development Board (BWDB) on identifying potential locations for establishing new hydroelectric power plants. The Brahmaputra river basin which is not utilized for extracting hydro energy has the potential of generating 1400 MW (Halder et al. 2015). Sustainable Rural Energy (SRE) found quite a few potential sites for establishing micro hydro plants in Khagrachari, Bandarban and Rangamati where total generation can be $135.5 \mathrm{MW}$ (Halder et al. 2015). Moreover, there is hydropower potential of around $35 \mathrm{MW}$ in total in the Meghalaya Rivers of the Northeast Region (Miskat et al. 2020). The prospective sites for Micro hydropower development in Chittagong Hill Tracts and the potential sites to established small scale hydropower sites identified by BPDB and BWDB are listed in by (Islam et al. 2008) and (Halder et al. 2015). Apart from national initiatives, the Bangladesh government has signed an energy cooperation agreement with Nepal to import up to 9,000 MW of hydropower from Nepal by 2040 (Hasanujzaman and Rimal 2020).

\subsubsection{Wind energy}

In order to harness wind energy, the wind speed of the desired location plays a huge role as the energy is proportional to the cube of wind speed. Hence, a project related to wind energy, requires an appropriate site to be viable. Unfortunately, Bangladesh is not in a suitable position to use wind energy for large scale grid connected production as the average wind speed required for such projects is more than $7 \mathrm{~m} / \mathrm{s}$ (Baky et al. 2017). A study carried out by the Bangladesh Center for Advanced Studies (BCAS) during 1996-1997 showed that the average wind speed in seven potential sites is between $2.94-4.52 \mathrm{~m} / \mathrm{s}$ at $25 \mathrm{~m}$ height. Hence, wind energy is rarely used in Bangladesh and that too only for small access generation. Considering the factors, in the Feni region, the BPDB has installed four grids connected wind turbine generators having a capacity of $225 \mathrm{KW}$ (Hossain et al. 2019). A project consisting of 50 turbines having a capacity of $20 \mathrm{~kW}$ each was installed in 2008 in Kutubdia as well (SREDA 2021). Recently, the BPDB has taken the decision to renovate the $1000 \mathrm{~kW}$ wind based power plant located in Kutubdia and steps have been taken to us the coastal regions of Kuakata, Barguna and Chittagong to generate $15 \mathrm{MW}$ power from wind energy (Bosu 2019). There is a future plan of the BPDB to establish 50-200 MW power plants based on wind energy at Parky Beach, Chattogram (Islam et al. 2014). 


\subsubsection{Biogas, biomass and other renewable sources}

Another available source of renewable energy in Bangladesh is Biogas, which is basically a mixture of multiple gases obtained from the decomposition of organic materials like dead animals or plants. The composition of biogas varies, but mostly contains $35-60 \% \mathrm{CO}_{2}, 45-70 \%$ methane and $1-5 \%$ of other gases (Bosu and Rafiq 2019). In Bangladesh the cattle farms can use this method of power generation. At present, there are two power plants operating on Biogas of a $400 \mathrm{~kW}$ and $50 \mathrm{~kW}$ capacity funded by the IDCOL. Cattle manure produced in Bangladesh can be effectively used to run biogas plants. Each ton of this manure contains $37 \mathrm{~m}^{3}$ equivalent of biogas. In Bangladesh about 155.8 million tons of dung is produced annually and utilization of $10 \%$ of that would provide 1.57 million $\mathrm{m}^{3}$ of biogas every day (Ministry of Fisheries and Livestock 2016). Each cubic meter of biogas approximately contains $6-6.5 \mathrm{kWh}$ energy but when used for electricity generation, only $2 \mathrm{kWh} / \mathrm{m}^{3}$ is available due to lower generator efficiency (Korres et al. 2013). Thus, there is a future scope of $1146.1 \mathrm{MWh}$ of electricity only from this source annually. Again, the main sources of biomass for electricity generation are rice husk and straw which are rice bi-products. Being an agricultural country, almost $10.13 \times 10^{6}$ tons of rice husk is produced in Bangladesh annually; of which around $50 \%$ is suitable for electric power production (Khan et al. 2015).

\subsection{Existing policies on energy sector in Bangladesh}

There were three legislations regarding electricity before the independence of Bangladesh in 1971, i.e. The Electricity Act 1910; The Electricity Rules 1937; and The Electricity Regulations, 1961. From 1996, Bangladesh has prepared a number of acts, rules, policies regarding power sector reform, as a result, a number of institutions have been created. The first National Energy Policy (NEP) of Bangladesh was formulated in 1996 by the Ministry of Power, Energy and Mineral resources (abbreviated as MPEMR) also known as the Ministry of Energy (Ministry of Power, Energy and Mineral Resources 2004) was to ensure proper exploration, production, distribution and rational use of energy resources to meet the growing energy demands (Ministry of Power Energy and Mineral Resources 2004). Afterwards the NEP was revised in 2004 with an aim to bring the entire country under electrification by the year 2020 (Ministry of Power, Energy and Mineral Resources 2004).

In 1996, the "Private Sector Power Generation Policy of Bangladesh" was approved and later in 2004 it was revised by the Government with a view to boost up power generation by private sectors in the country (Ministry of Power, Energy and Mineral Resources 2004). In order to implement the formulated policies into actual an investment project created by the Government of Bangladesh (GOB) and set up a Power Cell under (MPEMR) in 1995 (Ministry of Power, Energy and Mineral Resources 2004). Responsibilities of the private sector power development area belongs to this Cell. The Cell solicits and evaluates proposals, negotiates and processes 
award of contracts and finalizes projects. Initially in the National Energy Policy the formation of a Renewable Energy Developments Agency (REDA) was decided under the MPEMR for the development, dissemination and/or extension of different types of renewable energy technologies (Ministry of Power, Energy and Mineral Resources 2004). In 2000, the GOB adopted Policy Guidelines for Small Power Plant (SPP) in Private Sector, 2000 for introducing the public-private partnership (PPP) approach in the power sector.

The government has established a regulatory body to regulate the electricity, gas and petroleum sector called the Bangladesh Energy Regulatory Commission (BERC) under Energy Regulatory Commission (Act No.13 of 2003). In 2004, the government prepared the Bangladesh Private Sector Infrastructure Guidelines in 2004, which promoted private sector participation through Independent Power Producers (IPPs). During 2007 and 2008 a number of policy guidelines were formulated to cover different issues such as Policy Guidelines for Power Purchase from Captive Power Plant, 2007; Policy Guidelines for Public Private Partnership 2008; Guidelines for Remote Area Power Supply System (RAPSS) (Minister and Government 2004), 2008; and Policy Guidelines for the Enhancement of Private Participation in the power Sector, 2008.

The major initiatives on renewable energy started after approving the Renewable Energy Policy (REP) in 2008 (Ministry of Power, Energy and Mineral Resources 2008). This policy was formulated considering facts such as the decline in fossil fuel availability, cut global emissions for mitigating climate change and to ensure energy security. This policy focuses on the efficient utilization of renewable energy resources. Afterwards in 2012, the Sustainable and Renewable Energy Development Authority (SREDA) Act was formulated (SREDA 2021). The SREDA acts as a focal point for renewable energy development, promotion and ensuring energy efficiency.

In 2010, the Power System Master Plan (PMSP 2010) was developed for the attainment of stable power supply in Bangladesh up to year 2030 in consideration of the diversification of fuel resources (PSMP 2010). Later on, the plan esd revised in 2016 to formulate the updated Power System Master Plan (MPMER 2016). This Seventh Five Year Plan (2016-2020) also emphasized the rapid growth in electricity generation especially from solar and wind and efficient use of energy.

\subsection{Comparison of renewable energy sectors of countries facing the worst climate risks}

Despite the difficulties, the Government of Bangladesh has taken several initiatives to boost the energy production from RE. According to the National Database of Renewable Energy established and maintained by the SREDA, Bangladesh has a total installed capacity of 25,181 MW, with $766.68 \mathrm{MW}$ (peak) renewable energy installed capacity which is fulling about $3.05 \%$ of the total energy share in the country (SREDA 2021). However, to better understand these numbers, the position of Bangladesh in terms of total energy and renewable energy production needs to 
analyze in a global perspective. According to the U.S. Energy Information Admission (EIA) 2018 report, Bangladesh ranked 50 among 174 countries with 1.141 Quadrillion British Thermal Unit (BTU) of equivalent energy production (EIA 2018). In terms of energy consumption Bangladesh ranked 39 among 190 Countries with 70.59 Billion kWh of annual energy consumption. From the information source of The U.S. Energy Information Administration, in 2019, Bangladesh had a renewable power capacity of 0.52 million kilowatts which placed the country into the $108^{\text {th }}$ place in the country ranking according to renewable power capacity (The Global Economy 2019).

As mitigating greenhouse gasses are major challenges not only for industrialized high carbon emission countries but also for every country in the world, atransition from conventional energy sources to sustainable energy production is vital to ensure a sustainable future. According to the Long-Term Climate Risk Index (CRI), the top 7 countries most affected from 1999 to 2018 are Puerto Rico, Myanmar, Haiti, Philippines, Pakistan, Vietnam, and Bangladesh (Eckstein et al. 2021). This study focused in brief, how these seven countries are shaping their renewable energy sectors to tackle the GHG problem. Puerto Rico, for instance, is at risk for rising sea level and severe storms as it is an island on the hurricane belt. Currently, the intensity of devastating hurricanes has increased due to the rise in global temperature (IPCC 2014). The Governor of Puerto Rico, Ricardo Rosselló, pledged that it will run completely on renewable energy by the year 2050 (Canty 2021).

Myanmar is also facing significant impacts from climate change. The main drivers of impact are extreme warming and drying trends, sea level rise, and damaging cyclones. To tackle these severe conditions, Myanmar needs sustainable development to ensure it does not exhaust its rich environment. A long term goal is taken by the government to achieve climate-resilience and pursue a low carbon emission way to support sustainability within 2030 (MONREC 2019).

Haiti faced many changes in the climate in the past years. Haiti faces extreme weather conditions like drought in the warm season and hurricane and storms in the rainy season. The country lies in the primary core of tropical storms which arise in the Atlantic Ocean and frequently get struck by them which leads to flooding, erosion and deforestation. An initiative has been taken to use and promote biofuel crops like sugarcane and corn to produce ethanol and biodiesel. Another feasible long term initiative is the use of renewable energy technologies, such as solar and wind, for which Haiti has a massive potential.

The Philippines is another most unfortified country to climate change. The government has increased financing, and has a greater focus and coordination towards climate change programs, and is promoting renewable energy to reduce the amount of pollution.

For many years, Pakistan has been frequently ranked one of the most vulnerable countries by climate change. Flash floods due to glacial melting, increased heat waves, rising sea levels are some of the main reasons for climate change. A policy has been taken for implementation by the government of Pakistan for the National Environment. The objective of this policy is multi-sector projects with opportunities for climate resilient agriculture, disaster management, renewable energy for power generation etc. 
Huge growth in Vietnam dramatically mitigated poverty from $49.2 \%$ in 1993 to $3.2 \%$ in 2012, however, it also put detrimental effects on the natural resources of the country. In terms of boosting up the renewable energy production capacity, Vietnam has performed a tremendous job among the South and South East Asian nations. According to IRENA renewable energy statistics 2021, the total RE installed capacity of Vietnam is 35649 MW (IRENA 2021). As of 2020, solar and wind capacity in Vietnam reached approximately $16.6 \mathrm{GW}$ and $0.6 \mathrm{GW}$, respectively, and the government of Vietnam has a plan to increase solar capacity to $18.6 \mathrm{GW}$ and wind capacity to $18.0 \mathrm{GW}$ by 2030 (EIA 2021). Similar to Bangladesh, solar energy (54\% in 2020) dominates the major share of renewable energy mix in Vietnam (Nguyen et al. 2021).

To evaluate the RE usage of the above mentioned countries, a comparative analysis has been performed in terms of RE capacity among these countries. This comparative analysis presented in Table 2 will help to understand where Bangladesh stands in this regard in comparison with the other six countries in the list.

TABLE 2. Comparative study of the energy sector of the country's worst hit by climate change

TABELA 2. Studium porównawcze sektora energetycznego najbardziej dotkniętego zmianami klimatycznymi w kraju

\begin{tabular}{|c|c|c|c|c|}
\hline Country & $\begin{array}{l}\text { Total installed } \\
\text { capacity }[\mathrm{MW}] / \\
\text { referred year }\end{array}$ & References & $\begin{array}{c}\text { Total renewable } \\
\text { energy installed } \\
\text { capacity in } 2020 \\
\text { [MW] }\end{array}$ & $\begin{array}{c}\text { Total electricity } \\
\text { production capacity } \\
\text { from renewable energy } \\
\text { in } 2019 \\
\text { [GWh] }\end{array}$ \\
\hline Puerto Rico & $\begin{array}{l}6,000 \mathrm{MW} \\
\text { (in 2018) }\end{array}$ & EIA 2018 & 363 & 457 \\
\hline Myanmar & $\begin{array}{l}6,034 \mathrm{MW} \\
\text { (in 2018) }\end{array}$ & $\begin{array}{l}\text { Vakulchuk, Stokke } \\
\text { and Overland } 2018\end{array}$ & 3,448 & 13,229 \\
\hline Haiti & $\begin{array}{l}313 \mathrm{MW} \\
\text { (in 2019) }\end{array}$ & $\begin{array}{l}\text { Haiti: Renewable Energy } \\
\text { for All } 2020\end{array}$ & 81 & 103 \\
\hline Philippines & $\begin{array}{l}27,600 \mathrm{MW} \\
\text { (in 2020) }\end{array}$ & Global data 2021 & 3761 & 8,025 \\
\hline Pakistan & $35,975 \mathrm{MW}$ & Mustafa 2020 & 12,406 & 42,599 \\
\hline Vietnam & $\begin{array}{l}54,880 \mathrm{MW} \\
\text { (in 2019) }\end{array}$ & Statista 2021 & 35,649 & 98,282 \\
\hline Bangladesh & $\begin{array}{l}25,181 \mathrm{MW} \\
\text { (in 2021) }\end{array}$ & SREDA 2021 & 230 & 812 \\
\hline
\end{tabular}

Source: Renewable Energy Statistic 2021 (IRENA 2021).

From Table 2, it can be seen that, Vietnam has the highest energy generation capacity while Haiti has the lowest energy production capacity. One of the reasons for this huge difference of generation capacity between the two countries is the area and population. The power generation capacity in Puerto Rico and Myanmar is almost the same. Moreover, The Philippines and Ban- 
gladesh have the similar generation capacity which is around 20,000 MW. It is also quite visible that the renewable energy share is much higher in Haiti than Bangladesh as total generation capacity is lower in Haiti and use of bio-fuel produced from Jatropha plant which is not quite available is Bangladesh. Also, the renewable energy share of Pakistan and Vietnam is also slightly higher compared to Bangladesh. Although inconsistent and non-uniform wind, non- availability of geothermal energy, plane river watercourse which is not appropriate to utilize hydropower does not give Bangladesh much option to use renewable energy, significant importance should be given to sources which could be viable RE sources. Solar, Biogas, Biomass could be a feasible sources to boost up energy production from RE.

\section{Conclusion and recommendations}

Being the ninth largest country in the world by population and an energy-poor nation, the demand is increasing and the government is trying to boost electricity production. The country's economy is transitioning away from its agriculture sector to the industrial sector. Therefore, electricity generation is needed from both renewable and non-renewable sectors. The existing power plants of Bangladesh are mostly gas and oil-fired types. Gas has been taken from internal limited resources and oil is imported from for foreign countries. The government should reduce dependency on these two primary fuels, as climate change is expected to have severe effects on energy production and consumption. Though Bangladesh is a climate risk country it needs to try to achieve Zero Carbon Solutions as stated in the Paris Agreement. The following recommendations are outlined in this study:

Bangladesh is currently excessively dependent on gas-fired electricity generation therefore the transition to coal-based power plants is the main option to produce electricity generation. However, becoming more dependent on imported coal should not be the main option and the steps that the present government is taking seem positive for ensuring clean and green energy in Bangladesh as well as achieving the Paris Agreement. It can be added here that coal-fired power plants are cheaper than any other plants. Though Bangladesh is an energy poor country they should use "Clean coal technology" to reduce harsh environmental effects by using multiple technologies to clean coal and contain its emissions. As a climate risky country, the country should do conduct an Environmental Impact Assessment or Strategic Impact Assessment (if necessary) before implementing a coal-based power plan to avoid complications and risks going forward.

Again, the expansion of solar based power plants and implementing energy efficiency policies can reduce the dependency on coal-based power. It will also enhance larger, long-term cost-competitive energy supply and ensure energy security. It is very impressive that Bangladesh is scaling up solar programs. Therefore, Bangladesh should maintain its status quo as well as the expand endorsement in investment and financing, which can enhance energy security. 
Bangladesh is also facing severe environmental impact from the global warming. Being one of the countries with lower greenhouse gas emission, and at the same time facing the consequences of the global warming is a huge burden for Bangladesh. But, the important fact is what the progress of the sustainable energy sector is in Bangladesh despite the situation. From the comparisons drawn in this paper comparing to the worst climate risky countries, it is seen that Bangladesh is not doing so badly when compared to other top climate countries affected severely by climate change. However, progress is not enough as Bangladesh is lagging behind to catch up its planned capacity to produce electricity from renewable energy sources including utilizing renewable energy sources from neighboring countries (IRENA 2021). Although inconsistent and non-uniform wind, non- availability of geothermal energy, plane river watercourse which is not appropriate to utilize hydropower does not give Bangladesh much option to use renewable energy, significant importance should be given on sources which could be viable RE sources. Solar, Biogas, Biomass could be a feasible sources to boost up energy production from RE.

Energy is not only a key strategic sector in the present world in terms of competition but also to future development and sustainability. Vietnam has gained successive growth due to its highest energy generation capacity; Bangladesh should take necessary steps to increase the energy generation from renewable energy sources as it is the purest form of energy. Though competitive agencies are playing an active role in wider utilization of renewable energy in Bangladesh, the government must take efforts to achieve its status quo to attain greater renewable energy share in the coming years to gain status in middle income country. Finally, national and international donor agencies should increase investment in order to expand the growth of renewable sector in Bangladesh.

\section{References}

Ahsan, M.M. 2020. Climate Change Adaptation-Based Strategies on Water and its Security: A Study on Dhaka and Ankara. Güvenlik Bilimleri Dergisi, vol. Özel Sayı, no. International Security Congress Special Issue, pp. 79-93, Feb. 2020, DOI: 10.28956/gbd.695924.

Bangladesh Bureau of Statistics (BBS) 2019. Report on Bangladesh Sample Vital Statictis [Online] https://web.archive.org/web/20200110115455/http://bbs.portal.gov.bd/sites/default/files/files/bbs.portal. gov.bd/page/6a40a397_6ef7_48a3_80b3_78b8d1223e3f/SVRS_Report_2018_29-05-2019(Final).pdf. [Accessed: 2021-09-08].

BaKy et al. 2017 - BaKy, A.H., Rahman, M.M. and Islam, A.K.M. 2017. Development of renewable energy sector in Bangladesh : Current status and future potentials. Renewable and Sustainable Energy Reviews (April 2016) 73, pp. 1184-1197, DOI: 10.1016/j.rser.2017.02.047.

Bosu, A.K. and RafiQ, M.A. 2019. Future of Renewable Energy in Bangladesh as a Potential Solution to Energy Crisis. $20195^{\text {th }}$ International Conference on Advances in Electrical Engineering (ICAEE), 2019, pp. 909-914, DOI: 10.1109/ICAEE48663.2019.8975473.

Canty, M.M. Climate Change in Puerto Rico. How Climate Change Affects the People of Puerto Rico. [Online] http://www.aksik.org/node/3597 [Accessed: 2021-09-08]. 
Climate Watch 2018. Historical GHG Emissions. [Online] https://www.climatewatchdata.org/ghg-emissions? calculation=ABSOLUTE_VALUE\&end_year=2018\&regions $=$ SAR\&start_year=1990 [Accessed: 2021-09-08].

Deb et al. 2013 - Deb, A., Bhuiyan, D.M.A.M. and Nasir, A. 2013. Prospects of Solar Energy in Bangladesh. IOSR Journal of Electrical and Electronics Engineering 4(5), pp. 46-57, DOI: 10.9790/16760454657.

ECKSTEIN et al. 2021 - Eckstein, D., KÜNZel, V. and SchÄFER, L. 2021. Who Suffers Most from Extreme Weather Events? Weather-Related Loss Events in 2019 and 2000-2019. GLOBAL CLIMATE RISK INDEX 2021. [Online] https://germanwatch.org/sites/default/files/Global Climate Risk Index 2021_1. pdf [Accessed: 2021-09-08].

EIA 2018a. U.S. Energy. Information Administration 2018. Total energy production 2018 Ranking. [Online] $\mathrm{https} / / /$ www.eia.gov/international/rankings/world? $\mathrm{pa}=12 \& \mathrm{u}=0 \& \mathrm{f}=\mathrm{A} \& \mathrm{v}=$ none $\& \mathrm{y}=01 \% 2 \mathrm{~F} 01 \% 2 \mathrm{~F} 2018$ [Accessed: 2021-09-08].

EIA 2018b. U.S. Energy. Information Administration 2018. Puerto Rico Territory Energy Profile. [Online] https://www.eia.gov/state/print.php?sid=RQ [Accessed: 2021-09-08].

EIA 2021. U.S. Energy. Information Administration 2021. Vietnam's latest power development plan focuses on expanding renewable sources. [Online] https://www.eia.gov/todayinenergy/detail.php?id=48176 [Accessed: 2021-09-08].

ERAKHrumen, A.A. 2014. Growing pertinence of bioenergy in formal/informal global energy schemes: Necessity for optimising awareness strategies and increased investments in renewable energy technologies. Renewable and Sustainable Energy Reviews 31, pp. 305-311, DOI: 10.1016/j.rser.2013.11.034.

General Economics Division (GED) 2020. Making Vision 2041 a Reality PERSPECTIVE PLAN OF BANGLADESH 2021-2041. [Online] http://oldweb.lged.gov.bd/UploadedDocument/UnitPublication/1/1049/vision 2021-2041.pdf [Accessed: 2021-09-08].

Global data 2021. Philippines power capacity expected to grow more than twofold by 2030, says Global Data. [Online] https://www.globaldata.com/philippines-power-capacity-expected-grow-twofold2030-says-globaldata/ [Accessed: 2021-09-08].

Halder et al. 2015 - Halder, P. K., Paulb, N., JoARdDerc M.U.H. and SARKer, M. 2015. Energy scarcity and potential of renewable energy in Bangladesh. Renewable and Sustainable Energy Reviews. 51, pp. 1636-1649, DOI: 10.1016/j.rser.2015.07.069.

HaSANuJZAman, M. and RimaL, R.R. 2020. Bangladesh-Nepal energy cooperation; the horizon of new possibilities. The Himalayan. [Online] https://thehimalayantimes.com/business/bangladesh-nepal-energycooperation-the-horizon-of-new-possibilities [Accessed: 2021-09-08].

Hossain, S. and Rahman, M. 2021. Solar Energy Prospects in Bangladesh: Target and Current Status. Energy and Power Engineering 13, pp. 322-332, DOI: 10.4236/epe.2021.138022.

Hossain et al. 2019 - Hossain, S., Rahaman, M., Tasnim, I. and Mohammad, N. 2019. Optimal Energy Mix and Operation Cost in the Presence of Nuclear and Solar PV Generation. 2019 International Conference on Electrical, Computer and Communication Engineering (ECCE), 2019, pp. 1-6, DOI: 10.1109/ECACE.2019.8679472.

Imam, B. 2021. Power Generation in Bangladesh: Important facts to look at. [Online] https://www.thedailystar.net/opinion/news/power-generation-bangladesh-important-facts-look-2052261 [Accessed 2021-09-08].

Intergovernmental Panel on Climate Change (IPCC). AR5 Synthesis Report: Climate Change 2014. [Online]. https://www.ipcc.ch/report/ar5/syr/ [Accessed: 2021-09-08].

IRENA 2021 - IRENA - International Renewable Energy Agency 2021. Renewable Energy Statistics 2021. [Online] https://www.irena.org/publications/2021/Aug/-/media/DE99E76D009042DE9A01F724A0CFBE9F.ashx. [Accessed: 2021-09-08]. 
IsLAM, M.R. and BEG, M.R.A. 2008. Renewable energy resources and technologies practice in Bangladesh. Renewable and Sustainable Energy Reviews 12(2), pp. 299-343, DOI: 10.1016/j.rser.2006.07.003.

IsLAm et al. 2014 - Islam, M.T., ShahIR, S.A., UdDin, T.M.I. and SAIfUllah, A.Z.A. 2014. Current energy scenario and future prospect of renewable energy in Bangladesh. Renewable and Sustainable Energy Reviews 39, pp. 1074-1088, DOI: 10.1016/j.rser.2014.07.149.

Khan et al. 2015 - Khan, A.H., Zafreen, K.R., Hossain, M.M. and Islam, M. 2015. A review of current renewable energy activities in Bangladesh. 2015 International Conference on Green Energy and Technology, ICGET 2015. 2015, pp. 1-5, DOI: 10.1109/ICGET.2015.7315097.

Korres et al. 2013 - Korres, N., O’Kiely, P., Benzie, J.A.H. and Jonathan, S.W. 2013. Bioenergy Production by Anaerobic Digestion: Using Agricultural Biomass and Organic Wastes.

Masud et al. 2020 - Masud, M.H., Nuruzzaman, M. Ahamed, R. and Tomal, A.N.M.A. 2020. Renewable energy in Bangladesh: current situation and future prospect. International Journal of Sustainable Energy 39(2), pp. 132-175, DOI: 10.1080/14786451.2019.1659270.

Ministry of Fisheries and Livestock, Bangladesh 2016. Draft National Integrated Livestock Manure Management Policy. [Online] https://www.ccacoalition.org/en/resources/manure-management-draft-national -integrated-livestock-manure-management-policy [Accessed: 2021-09-08].

Ministry of Power, Energy and Mineral Resources (MPEMR) 2004. NATIONAL ENERGY POLICY. [Online] https://gtcl.org.bd/wp-content/uploads/2018/02/NATIONAL-ENERGY-POLICY.pdf [Accessed: 2021-09-08].

Ministry of Power Energy and Mineral Resources 2004. Private Sector Power Generation Policy of Bangladesh. Fuel (October 1996), pp. 1-10.

Ministry of Power Energy and Mineral Resources (MPEMR) 2008. Renewable Energy Policy of Bangladesh. [Online] https://policy.thinkbluedata.com/sites/default/files/REP_English.pdf [Accessed: 202109-08].

Miskat et al. 2020 - Miskat, M.I., Ahmed, A., Rahman, M.S., Chowdhury, H., Chowdhury, T., ChowDHURY, P., SAIT, S.M. and PARK, Y. 2020. An overview of the hydropower production potential in Bangladesh to meet the energy requirements. Environmental Engineering Research 26(6), 200514, DOI: 10.4491/eer.2020.514.

MONREC 2019. Myanmar Climate Change Strategy (2018-2030). Food and Agriculture Organization of the United Nations. [Online] http://www.fao.org/faolex/results/details/en/c/LEX=-FAO191077C/\#: :textThis\%20Myanmar\%20Climate\%20Change \%20Strategy,support $\% 20$ inclusive $\% 20$ and $\% 20$ sustainable\%20development [Accessed: 2021-09-08].

MPMER 2016. Power System Master Plan 2016, Final Report. Power Division, Ministry of Power, Energy and Mineral Resources, Bangladesh.

MPEMR 2020. Ministry of Power, Energy and Mineral Resources Report, Fiscal Year 2019-20. [Online] https://powerdivision.gov.bd/sites/default/files/files/powerdivision.portal.gov.bd/annual_reports/7d86d53d_5ebb_408d_8839_64d1a9eea653/ANNUAL\%20REPORT-\%202019-2020\%20.pdf [Accessed: 2021-09-08].

Mustafa, K. 2020. Pakistan's power generation capacity increases to 35,975 MW. International The News. [Online] https://www.thenews.com.pk/print/671530-pakistan-s-power-generation-capacity-increases -to-35-975mw [Accessed: 2021-09-08].

Nguyen et al. 2021 - Nguyen, X.P., Le, N.D., Pham, V.V., Huynh, T.T., Dong, V.H. and Hoang, A.T. 2021. Mission, challenges, and prospects of renewable energy development in Vietnam. Energy Sources, Part A: Recovery, Utilization and Environmental Effects. Taylor \& Francis, pp. 1-13, DOI: 10.1080/15567036.2021.1965264.

PSMP 2010. Power System Master Plan 2010. [Online] https://policy.asiapacificenergy.org/sites/default/ files/PSMP2010_reduced.pdf [Accessed: 2021-09-08]. 
Roy, P. 2021. Govt scraps 10 coal power projects. [Online] https://www.thedailystar.net/frontpage/news/ govt-scraps-10-coal-power-projects-2118089 [Accessed: 2021-09-08].

SaIm, M.A. and Khan, I. 2021. Problematizing solar energy in Bangladesh: Benefits, burdens, and electricity access through solar home systems in remote islands. Energy Research and Social Science, DOI: 10.1016/j.erss.2021.101969.

SajJad, M. and Rasul, M.G. 2015. Prospect of underground coal gasification in Bangladesh. Procedia Engineering 105, pp. 537-548, DOI: 10.1016/j.proeng.2015.05.087.

SREDA 2021. Sustainable And Renewable Energy Development Authority. Electricity Generation Mix. [Online] http://www.renewableenergy.gov.bd/index.php?id=7 [Accessed: 2021-09-08].

Statista 2021. Annual installed power capacity in Vietnam from 2015 to 2019. [Online] https://www.statista. com/statistics/1196781/vietnam-total-installed-power-capacity/ [Accessed: 2021-09-08].

The Daily Star 2021. Current gas reserve to last 16 yrs. [Online] https://www.thedailystar.net/city/currentgas-reserve-suffice-16yrs-104212 [Accessed: 2021-09-08].

The Global Economy, Business and Economic data for 200 countries 2019. Renewable power capacity Country rankings. [Online] https://www.theglobaleconomy.com/rankings/renewable_power_capacity/ [Accessed: 2021-09-08].

The World Bank. Haiti: Renewable Energy for All. [Online] https://projects.worldbank.org/en/projects -operations/project-detail/P156719 [Accessed: 2021-09-08].

The World Bank 2018. World Development Indicators Data. Washington, D.C.: World Bank Group 2018.

Worldometer 2021. Bangladesh Population. [Online] https://www.worldometers.info/world-population/ bangladesh-population/. [Accessed: 2021-09-08].

\section{Przejście do zrównoważonej produkcji energii: co jest najtrudniejsze dla Bangladeszu w związku ze zmianami klimatu?}

\section{Streszczenie}

Ocenia się, że Bangladesz jest siódmym najbardziej zagrożonym zmianami klimatu krajem na świecie, położonym w Azji Południowej. Postępujący wzrost gospodarczy, szybka industrializacja i inne działania na rzecz rozwoju przekształcają Bangladesz w kraj o średnich dochodach. Aby sprostać szybkiemu wzrostowi gospodarczemu, podaż energii musi odpowiadać zapotrzebowaniu na nią. Ale energia stanowi centralny problem związany z wyzwaniem klimatycznym, ponieważ dwie trzecie światowych emisji gazów cieplarnianych pochodzi z sektora energetycznego. Obecnie w Bangladeszu około 62\% energii elektrycznej jest produkowana $\mathrm{z}$ gazu ziemnego, ale jego zapasy szybko się wyczerpują z powodu zwiększonego tempa wydobycia i wykorzystania. Mając na uwadze niedobór zasobów naturalnych oraz fakt, że Bangladesz jest krajem bardzo dotkniętym zmianami klimatycznymi, należy dokonać oceny istniejącego stanu, perspektyw na przyszłość i polityk związanych z energią odnawialną, aby istniejący sektor energetyczny był bardziej 
zrównoważony i nowoczesny. W tej pracy przedstawiono dokładny opis źródeł wtórnych sektora energetycznego w Bangladeszu, ze szczególnym uwzględnieniem obecnego scenariusza i przyszłych perspektyw wytwarzania energii elektrycznej, istniejących problemów politycznych związanych z wykorzystaniem różnych odnawialnych źródeł energii. Ponadto dokonano porównania postępów w sektorze energii odnawialnej Bangladeszu z krajami najbardziej dotkniętymi globalnymi zmianami klimatycznymi. To porównanie pozwala ocenić, w jaki sposób Bangladesz dokonuje zrównoważonej transformacji energetycznej, stawiając jednocześnie czoła problemom wynikającym ze zmian klimatu. Na koniec przedstawiono zalecenia dotyczące przyspieszenia rozwoju energii w Bangladeszu w celu przekształcenia go w zrównoważony sektor energetyczny.

SŁOWA KLUCzOWE: sektor energetyczny, energia odnawialna, zmiany klimatyczne, polityka energetyczna, Bangladesz 
